\title{
TEKST PUBLICYSTYCZNY W ROZWIJANIU KOMPETENCJI KOMUNIKACYJNEJ NA POZIOMIE C2 CECHY MEDIALNEGO DYSKURSU PUBLICZNEGO I POLITYCZNEGO
}

Słowa kluczowe: glottodydaktyka, tekst, dyskurs, komunikowanie polityczne, media

Streszczenie. Celem artykułu jest omówienie cech wybranego typu materiału dydaktycznego, jakim jest medialny mówiony dialogowy tekst publicystyczny (w skrócie: MMDTP). Zakładam, że proponowany typ tekstu spełnia takie programowe wymogi na poziomie $\mathrm{C} 2$, jak: autentyczność, aktualność, interakcyjność, mediacyjność, dyskursywność, a w sposób szczególny służy rozwijaniu sprawności rozumienia i mówienia. Potencjał wybranego rodzaju tekstów jest planowany jako temat cyklu artykułów. Pierwszy z nich jest poświęcony cechom medialnego dyskursu publicznego i politycznego. Niniejszy artykuł składa się z trzech części: w pierwszej omówiono sposób przygotowania materiału dydaktycznego, korzyści i problemy związane z jego wykorzystaniem; w drugiej przybliżono wybrane cechy dyskursu publicznego i politycznego, które pozwalają trafniej zinterpretować sens interakcji; w trzeciej zamieszczono zapis trwającego 10 minut publicystycznego tekstu dialogowego, pobranego jako podcast ze strony Radia TOK Fm wraz z ćwiczeniami.

Głównym źródłem wiedzy o życiu publicznym i politycznym są dla przeciętnego odbiorcy media, gdyż to w nich toczy się komunikowanie polityczne. Ich rola nie ogranicza się jednak do przekazywania. Media są pełnoprawnym aktorem politycznym, wpływającym na formatowanie treści i dobór kadr. Zarówno tradycyjne, jak i tym bardziej nowe media są coraz ważniejszym środowiskiem stymulującym poznawczo kolejne pokolenia osób uczących się. Wszystko to sprawia, że tekst medialny staje się pożądanym materiałem (glotto)

*edyta.paluszynska@uni.lodz.pl, Uniwersytet Łódzki, Wydział Filologiczny, Zakład Lingwistyki Stosowanej i Kulturowej, Instytut Filologii Polskiej i Logopedii, ul. Pomorska 171/173, 90-236 Łódź. 
dydaktycznym, zwłaszcza, że dzięki postępowi technologicznemu jest szansa na przełamanie dominacji tekstów pisanych w nauczaniu i włączenie w większym stopniu tekstów mówionych (Data 2000), (Data 2001). R. Przybylska uzasadnia konieczność stworzenia elektronicznych baz tekstów przydatnych w dydaktyce, w tym plików dźwiękowych (Przybylska 2008, s. 31). Pedeutolodzy natomiast podkreślają konieczność kształcenia kompetencji medialnych nauczycieli różnych specjalności tak, aby znali metody analizy tekstów medialnych i mieli świadomość szybkich przemian mediasfery (Ogonowska 2013, s. 231). Pojawił się nawet termin dydaktyka mediów dla podkreślenia nowej jakości tego rodzaju kształcenia (Kron i A. Sofos 2008). U. Żydek-Bednarczuk postuluje, aby włączyć do dydaktyki języka obcego dyskurs jako płaszczyznę odniesienia do tekstów, a zwłaszcza dyskurs medialny i teksty medialne (Żydek-Bednarczuk 2014, s. 335). Refleksji teoretycznej towarzyszą publikacje metodyczne (Bucko 2017), (Rabiej 2010) i podręczniki (Kubiak 2009, 2012).

Niniejszy artykuł otwiera cykl poświęcony (glotto)dydaktycznemu potencjałowi medialnego mówionego dialogowego tekstu publicystycznego (MMDTP). W kolejnych publikacjach poruszone zostaną takie zagadnienia, jak: cechy medialnego dyskursu publicznego i politycznego, strategie interakcyjne i mediacyjne w dyskursie, językowe cechy mówionego dialogowego tekstu medialnego.

Pierwszy artykuł cyklu składa się z trzech części: w pierwszej zostanie scharakteryzowany tytułowy rodzaj tekstu jako materiału dydaktycznego (sposób przygotowania, możliwe trudności, atuty, korelacja z celami programowymi); w drugiej zostaną przybliżone wybrane cechy dyskursu publicznego i politycznego w celu ułatwienia recepcji tekstów; w trzeciej pojawi się propozycja metodyczna, zawierająca zapis przykładowego tekstu mówionego z ćwiczeniami.

\section{PRZYDATNOŚĆ MÓWIONEGO MEDIALNEGO DIALOGOWEGO TEKSTU PUBLICYSTYCZNEGO W (GLOTTO)DYDAKTYCE}

Wspomniany rodzaj tekstu, aby stać się wartościowym materiałem dydaktycznym, wymaga specjalnego przygotowania. Najpierw należy utrwalić go na nośniku, np. poprzez nagranie lub ściągnięcie ze strony internetowej danego medium podcastu, co umożliwi wielokrotne odtwarzanie na zajęciach. W wyniku nagrania nauczyciel otrzymuje tekst mówiony (TM), który warto również wtórnie zapisać, co ułatwi jego spowolnioną i przez to bardziej wnikliwą analizę pod różnymi kątami. Sama czynność zapisania TM jest dość pracochłonna (zapis 3 minut nagrania zajmuje średnio 1 stronę komputeropisu). Dodatkowo dialogowość i żywiołowość interakcji spowodowana różnicą stanowisk uczestników dyskusji oraz presją czasu może w pewnych momentach skutkować szybkim tempem ko- 
munikacji, nakładaniem się tur, niepłynnością mowy i różnymi jej niedoskonałościami (miejscami pojawiają się błędy zakłócające komunikację, niewyraźna wymowa). Ponadto interpunkcja, choć z założenia ma oddawać pewne cechy żywej mowy (pauzy, półpauzy, zawieszenie głosu, modalność), to nie umożliwia tego w sposób wystarczający (np. brak wyraźnej delimitacji wypowiedzeń, a więc potok składniowy; urwanie wypowiedzi na skutek nałożenia tury; brak znaków oddających intonację sygnalizującą np. ironię, kpinę, zdystansowanie, bagatelizowanie). $Z$ tego względu na zajęciach konieczne są zarówno nagranie, jak i zapis. Poza trudnościami związanymi z utrwaleniem mówionej odmiany języka należy wziąć pod uwagę poznawcze bariery materiału publicystycznego, jak: nasycenie tekstu nowymi terminami i wyrazami o niskiej frekwencji, występowanie skomplikowanych struktur zdaniowych, nawiązywanie do realiów kulturowych czy historycznych nieznanych studentom, sposób prowadzenia dyskursu (np. polemika $\mathrm{z}$ poglądami w różnym stopniu ujawnianymi w tekście lub wyrafinowany system aluzji), nieprzejrzystość toku rozumowania (Balkowska 2013, s. 285).

Pozyskanie dialogowego tekstu mówionego w celu uczynienia z niego materiału dydaktycznego nie jest więc tak proste, jak posłużenie się gotowym tekstem pisanym, np. z podręcznika, a nawet z prasy. Mimo tego z kilku powodów warto włączać tego rodzaju teksty do nauczania. Ogromnym ich atutem jest bowiem autentyczność. Nawet oczywiste mankamenty tych tekstów z punktu widzenia normy językowej (różnego rodzaju błędy) mają pewien walor w kształceniu kompetencji rozumienia globalnego, przygotowują do radzenia sobie w sytuacjach nieciągłości informacji, niezrozumienia niektórych elementów przekazu, a przecież w takich właśnie warunkach przebiega rzeczywista komunikacja ustna.

$\mathrm{Z}$ autentycznością mówionych tekstów dialogowych wiąże się ich potencjał w ukazywaniu rzeczywistego przebiegu interakcji oraz w podejmowaniu działań mediacyjnych przez rozmówców (strategie interakcyjne i mediacyjne będą tematem kolejnych artykułów).

Z punktu widzenia realizacji treści nauczania ważna jest aktualność MMDTP. W katalogu tematycznym przewidzianym dla poziomu C2 umieszczono między innymi takie obszary tematyczne, jak: państwo i społeczeństwo (organizacja państwa, święta i uroczystości państwowe, sytuacja polityczna i gospodarcza, najważniejsze polskie partie polityczne, emigracja, tożsamość, konflikty wewnętrzne, warunki życia w Polsce, przestępczość, korupcja, organy ścigania, wymiar sprawiedliwości, armia, podstawowe organizacje międzynarodowe, stosunki i konflikty międzynarodowe); media (prasa, radio, telewizja, Internet); inne tematy budzące zainteresowanie uczących się (np. aktualne informacje, wydarzenia polityczno-społeczne, warunki życia, poziom życia, religijność Polaków) (Programy nauczania ... s. 183-184). Trudno zrealizować wymóg aktualności bez wykorzystania bieżących przekazów medialnych, które zwłaszcza w środowisku egzolingwalnym zrównoważyłyby ponadczasowe treści podręcznikowe. 
Oddalając się nieco od kontekstu glottodydaktycznego, warto dodać, że w dydaktyce akademickiej medialny mówiony tekst publicystyczny (MMDTP) również może być wykorzystany na przedmiotach takich, jak: „Stylistyczna analiza tekstu”, „Analizy współczesnych dyskursów”, „Kultura języka”, „Kultura wypowiedzi publicznej”, „Skuteczna retoryka i argumentacja”. Przykładowe cele dydaktyczne, jakie można realizować na jego podstawie to: specyficzne cechy tekstów mówionych w odróżnieniu od tekstów pisanych, kognitywne i językowe eksponenty stylu publicystycznego, wymogi a praktyka zachowań językowych w mediach, wyznaczniki medialnego dyskursu publicznego i politycznego, interakcyjność i mediacja w dialogach i polilogach, przyjmowanie ról w zależności od sytuacji komunikacyjnej i celu, skuteczność komunikacyjna, bariery w komunikacji i wiele innych.

Problemy te, jak widać, w większości dotyczą kompetencji dyskursywnej i mogą zbliżać się do zagadnień podejmowanych w nauczaniu języka polskiego jako obcego, szczególnie na poziomie $\mathrm{C} 2$. Według założeń tego programu powinien on być przystosowany do specyficznych potrzeb grup uczących się. Proponowana problematyka z zakresu dyskursu publicznego i politycznego może być szczególnie przydatna w kształceniu specjalistycznym, np. politologów, dziennikarzy, socjologów, historyków, kulturoznawców. Tych uczestników kształcenia z pewnością zainteresują koncepcje komunikowania politycznego, mediatyzacja polityki, tabloidyzacja mediów, norma komunikowania publicznego. Ze wskazanego zakresu wiedzy o mediach i komunikowaniu istnieje co prawda naukowa literatura fachowa ${ }^{1}$, ale zasada poglądowości w nauczaniu wymaga tego, aby zobrazować przekazywane treści na konkretnych przykładach, tak, by uczący się miał szansę sam wyciągnąć wnioski na podstawie obserwacji dyskursu. Aby obserwacja ta była uważna i pogłębiona, należy zapoznać osoby uczące się z kluczem kategoryzacyjnym, który będzie wymagał podania specjalistycznej leksyki. Dzięki temu rozwój kompetencji lingwistycznej, która bazuje na wiedzy językowej - znajomości gramatyki, leksyki, ortografii i fonologii - przyczyni się do kształcenia kompetencji komunikacyjnej, obejmującej działania receptywne, produktywne, interakcyjne i mediacyjne w zakresie publicznej, prywatnej, edukacyjnej i zawodowej sfery życia (Programy nauczania ... s. 178). Poszukując uzasadnienia do poszerzenia bazy tekstów o mówione teksty publicystyczne, można powołać się na cele szczegółowe programu na poziomie C2, wedle których: „Uczący mają porozumiewać się w mowie i w piśmie z rodzimymi użytkownikami w różnych sferach życia oraz korzystać z rozmaitych źródeł informacji” (ibid., s. 178). Do komunikacji specjalistycznej, która dotyczy dziennikarzy, polityków

${ }^{1}$ Teoretyczne podstawy komunikowania politycznego, jego strukturę i formy prezentuje szeroko B. Dobek-Ostrowska (Dobek-Ostrowska 2006). Rolę mediów i dziennikarstwa przybliża M. Mrozowski (Mrozowski 2001). Zjawisko dyskursu publicznego badał m.in. M. Czyżewski (Czyżewski i in. 1997). Ciekawe rozważania na temat kompetencji polityków, aktywności politycznej społeczeństwa snują socjolodzy (Skarżyńska red. 2002). 
należy więc dodać sytuacje rozmów codziennych, nieformalnych, w których podejmowane są bieżące sprawy polityczne. Aby móc w nich uczestniczyć, należy nieco orientować się w specyfice dyskursu publicznego i politycznego. Wydaje się, że z tekstami politycznymi jest podobnie jak z tekstami artystycznymi: chociaż niewielu uczących się będzie miało okazję je tworzyć w sytuacji oficjalnej, to należy przynajmniej dążyć do kształcenia kompetencji receptywnych.

\section{CECHY MEDIALNEGO DYSKURSU PUBLICZNEGO I POLITYCZNEGO}

Dyskurs polityczny jest silnie związany z rywalizacją i podziałem na role sprawujących władzę oraz opozycji. Podstawowym celem komunikowania politycznego jest formułowanie programu, zdobywanie poparcia i walka o władzę. Najprostsza wypowiedź zyskuje interpretację pragmatyczną, tj. cel i sens, dopiero po ustaleniu parametrów sytuacji komunikacyjnej. Jako przykład można podać recepcję wypowiedzenia: „Media komercyjne płacą za niskie podatki”. W ustach decydenta, czyli kogoś sprawującego władzę, należy odebrać to jako akt komisywny, będący zobowiązaniem wprowadzenia zmiany, a mianowicie podwyższenia podatków. Jeśli odbiorca jest zwolennikiem projektowanej zmiany, to odczyta taki akt komisywny jako obietnicę, jeśli przeciwnikiem - odbierze to jako groźbę lub jeśli jest neutralny potraktuje to po prostu jako zwykłą zapowiedź. W ustach opozycji cytowana wypowiedź będzie stanowić krytykę nieudolności rządu, bo pozwala na taki stan, a więc wypowiedź należy odebrać jako akt dyrektywny, chęć wywarcia wpływu na władzę, aby zmieniła obecny stan rzeczy („,zrób coś z tym"). Możliwa jest również trzecia interpretacja. Jeśli nadawca jest poza układem decyzyjnym i nie ma żadnego interesu w krytykowaniu władzy, np. jest medioznawcą, który reprezentuje dyskurs naukowy, ekspercki, wówczas odbiorca zrozumie jego wypowiedź jako konstatację, mniej lub bardziej trafną poznawczo asercję. Tak więc uwikłanie aktorów politycznych w rywalizację zmienia strategie recepcji dyskursu. Poszczególnych wypowiedzi nie można rozumieć jako realnych opisów rzeczywistości, ale jako przejaw realizacji celów dyskursu: dążenia do zdobycia władzy, pozyskiwania wyborców, krytykowania przeciwników. Do tych podstawowych kategorii dyskursywnych (nadawca, odbiorca, role komunikacyjne i cel) można w zależności od potrzeb i zainteresowań studentów dodać bardziej szczegółowy klucz kategoryzacyjny związany na przykład z koncepcjami komunikowania politycznego (podejście behawioralne, strukturalno-funkcjonalne, interakcyjne, dialogowe i rynkowe) (Dobek-Ostrowska 2006, s. 135-141), mediatyzacją polityki (Oniszczuk 2011), (Adamik-Szysiak 2015), (Adamik-Szysiak 2016), (Molęda-Zdziech M. 2013), tabloidyzacją mediów (Fras 2010) i inne. 
Im gęstsza jest siatka pojęć ujmujących dyskurs polityczny, tym bardziej skomplikowany, ale i adekwatny jego obraz się wyłania dzięki bardziej zaawansowanym strategiom recepcyjnym. Dobierając tekst na zajęcia, należy się kierować nie tylko atrakcyjnością bieżącego tematu, ale również jego nasyceniem komentarzami odsłaniającymi ponadjednostkowe mechanizmy polityki. W dobrych audycjach dziennikarze bowiem, dbając o medialnego odbiorcę, wkładają wysiłek w wyjaśnienie, przybliżenie, przystępne zobrazowanie tej ważnej dziedziny życia społecznego. Od przygotowania zawodowego i talentu dziennikarza zależy jasność i klarowność jego wywodu, która czyni tekst mniej lub bardziej cennym materiatem dydaktycznym.

\section{PRZYKLAD MEDIALNEGO MÓWIONEGO DIALOGOWEGO TEKSTU PUBLICYSTYCZNEGO WRAZ Z ĆWICZENIAMI}

Tekst mówiony jest prymarnie przeznaczony do odsłuchania, ale (jak już wspomniano) dla celów dydaktycznych warto również go zapisać. Poniżej umieszczono zapis dziesięciominutowej radiowej rozmowy ${ }^{2}$, w której uczestniczył dziennikarz prowadzący i dwóch komentatorów. Na podstawie materiału zaproponowano ćwiczenia leksykalne (wraz z kluczem), których celem jest wprowadzenie bądź utrwalenie tematycznego słownictwa (ćwiczenia 1-7), interpretacja tekstu uwzględniająca specyfikę dyskursu, np. poprzez takie zagadnienia, jak: konstruowanie opisu sytuacji zgodnie z celami politycznymi, ocena działań polityka a jego rola, kreowanie wizerunku (ćw. 8-10)․․ Ćwiczenia są tak zaprojektowane, aby przede wszystkim rozwijać sprawność rozumienia ze słuchu i mówienia.

JW.: W „Poranku Radia TOK FM” Renata Kim - „Newsweek”.

RK: Dzień dobry.

JW.: Marcin Piasecki - „Rzeczpospolita”.

MP: Dzień dobry. Witam.

JW.: Ale czemu się śmiejesz? Powiedziałem dosłownie parę słów na razie.

MP: Słuchaj, uśmiecham się delikatnie, słysząc o poranku twój głos.

JW.: Widzicie Państwo, co się dzieje? Tu postawię kropkę. Nie zdążyłem zapytać wicerzecznika „Porozumienia” i zarazem radnego dzielnicy Bielany, czy ta katastrofa „Czajki” - awaria, przepraszam, „Czajki”, rozszczelnienie, jak się mówi w środo-

${ }^{2}$ Zapisana dyskusja była nadana na żywo 1.09.2020 roku o godzinie 8 w audycji Poranek Radia TOK FM. Prowadzącym dziennikarzem był Jan Wróbel (skrót: JW), rozmówcami Renata Kim (RK) oraz Marcin Piasecki (MP). Archiwalne audycje Radia TOK FM można pobrać na stronie radia $\mathrm{w}$ formie podcastów po wykupieniu dostępu.

${ }^{3} \mathrm{Z}$ powodu ograniczeń objętościowych artykułu nie zamieszczono całego scenariusza lekcji, a jedynie materiał mogący stanowić jego podstawę. 
wiskach sprzyjających Rafałowi Trzaskowskiemu, bo to jakoś tak brzmi niegroźnie - rozszczelnienie, to jednak nie spowoduje, że w ogóle ten pomysł budowania do końca niejasnej struktury, ruchu społecznego współpracującego z PO pod wodzą Rafała Trzaskowskiego po prostu diabli wzięli, że, no: „Ciszej nad tą trumną” jak by zacytować przedwojennego jeszcze klasyka. Renata Kim?

RK: Wydaje mi się, że Rafał Trzaskowski popełnił błąd, nie biorąc się za organizację swojego ruchu zaraz po wyborach, kiedy jeszcze jego zwolennicy byli bardzo zmobilizowani, bardzo czekali na ogłoszenie tego, jak miałby wyglądać taki ruch i ten moment entuzjazmu, ten moment mobilizacji chyba już niestety minął. Rozmawialiśmy o tym tydzień temu. I ja/

JW.: Ale przed „Czajką”!

RK: No przed „Czajką”. „Czajka” jest niestety potężnym pechem Rafała Trzaskowskiego, dlatego że zgodnie z jego obietnicą złożoną wczoraj nie będzie mowy o żadnym ruchu, nie będzie mowy o żadnych innych działaniach, dopóki awaria „Czajki” nie zostanie usunięta, a to potrwa. To jest o wiele poważniejsza awaria niż ta poprzednia i oczywiście Rafał Trzaskowski jako prezydent Warszawy ma rację i robi bardzo słusznie, że przede wszystkim zamierza zająć się sprawą, która dotyczy warszawiaków, czyli jego wyborców sprzed kilku lat. Jest gospodarzem tego miasta i musi się zająć tą awarią, natomiast niestety odkładanie tworzenia tego ruchu na bliżej nieokreśloną przyszłość sprawia, że on się staje coraz bardziej efemeryczny, coraz bardziej niepotrzebny, coraz bardziej nieuchwytny i/ no i wydaje mi się, że, no, że phy traci na powabie.

JW.: Ale wyobrażasz sobie, że ten ruch już istnieje, a dochodzi do rozszczelnienia w „Czajce”? Dopiero byłyby smutne miny aktywistów, prawda?

RK: No a dlaczego? Wydaje mi się, że to są zupełnie inne płaszczyzny: tutaj mamy gospodarza miasta stołecznego, a tutaj mamy ruch, który w założeniu miał objąć tych wszystkich Polaków, którzy popierają projekt Nowej Solidarności Rafała Trzaskowskiego, ja nie widzę w ogóle tutaj nawet takiego momentu, w którym się przecinają i utrudniają sobie działanie te dwie płaszczyzny.

JW.: Mhm. Marcinie, czas już wyjść ze stanu rozanielenia wywołanego, jak mniemam, wysłuchiwaniem/ słuchaniem głosu Renaty Kim, bo jeśli mój cię rozanielił, to cóż dopiero/ z głosem Renaty. Moim zdaniem to jest najlepszy radiowy głos w Polsce.

MP: No, to jest rzeczywiście, rzeczywiście tutaj kwestia do takiej, bym powiedział, bardzo, bardzo pozytywnej dyskusji i generalnie/ bo/ tak zgadzam się z tobą. I być może jeszcze jest kilka równie pięknych głosów, ale jak mówię, to jest kwestia do dyskusji, natomiast wracając do Rafała Trzaskowskiego/

JW.: O! Dziękuję.

RP: Rzeczywiście, jeżeli w polityce, no, istnieje taka kategoria jak pech, no to faktem jest, że Rafał Trzaskowski ma, no, dosyć dużego pecha związanego właśnie z awarią „Czajki” w ogóle i awarią „Czajki” właśnie w tym momencie, kiedy miał ogłosić właśnie start/ jakieś konkrety dotyczący/ dotyczące swojego ruchu. Natomiast jest pytanie, czy ta inicjatywa została tym sposobem, no, jakoś pogrzebana? Czy rzeczywiście nie jest tak, jak mówi Renata, że to jest w ogóle wszystko za późno? Że od tych emocji bezpośrednich, jakby emocji wyborczych już jest/ minęło zbyt dużo czasu, w związku z czym nie ma dla Trzaskowskiego tego paliwa, tak, tego paliwa, które było jeszcze podczas wyborów, tych emocji, zaangażowania ludzi i tak dalej i tak dalej. No a „Czajka” to wszystko mogła dobić. Zgoda. Taki scenariusz jest możliwy, z jednym zastrzeżeniem: trzeba pamiętać o tym, że paliwa dla opozycji, paliwa dla działań takich kontrujących bardzo często w Polsce dostarcza, no, nikt inny, jak obóz Zjednoczonej Prawicy i w związku z tym dla mnie wyobrażalna jest sytuacja taka, że na zasadzie, no, kolejnych 
pomysłów, ruchów, zmian, które wymyśli np. PiS, chociaż tutaj też Zbigniew Ziobro jest ostatnio bardzo aktywny i będzie próbował to wszystko wprowadzić w życie, no odrodzi się ten odruch buntu wobec tychże pomysłów, tychże ruchów, no i w związku z tym dla świeżego ciała ruchu społecznego, ruchu politycznego, no, znajdzie się to paliwo po prostu na zasadzie kontry. Oczywiście, ja uważam/ jestem przekonany o tym od dawna, że działanie na zasadzie anty-PiS-u nie jest jednak pozbawione politycznego sensu w Polsce.

JW.: Tylko czy nie jest tak, że przylgnęła/ przylgnie albo właśnie przylgnęła do Rafała Trzaskowskiego taka opinia, że inteligentny człowiek, zna języki, ładnie mówi, ale bardzo nieskuteczny. Co myślicie, że rok po roku/ po poprzednim rozszczelnieniu mamy inne rozszczelnienie i to, jak słyszeliśmy, dzień później, kiedy zakończono kontrolę tej rury, która się miała nie rozszczelniać, no to jak uciec od takiego wizerunku człowieka, który może i dobrze mówi, tylko do działania to/ to nie?

RK: Ja mam na pewno rozwiązanie tego problemu: zamknąc telewizję publiczną, która cały czas gra na tej nucie i opowiada, że Rafał Trzaskowski jest winny osobiście rozszczelnieniu oczyszczalni ścieków „Czajka”. To oczywiście nie jest prawda i słusznie, że się przypomina, że decyzja o budowie „Czajki” w takiej formie została podjęta za czasów rządów PiS poprzednich, więc jeśli ktokolwiek jest winny „Czajce” i temu, że ona się od czasu do czasu psuje, to być może budowniczy oraz pomysłodawcy tej oczyszczalni ścieków. Nie wydaje mi się, żeby można było tak prosto skleić Rafała Trzaskowskiego z niegospodarnością czy z nieudolnością, bo to po prostu nie jest prawda i też wydaje mi się, że sklejenie „Czajki” z ruchem też nie ma wielkiego sensu, bo po prostu obraża zdrowy rozsądek i po prostu się nie łączy. Chociaż, jeśli można, bo tak się wszyscy rozczuliliśmy i wszyscy jesteśmy bardzo mili. Ja wysłuchałam Jana Strzeżka w rozmowie przed nami i on właściwie co drugim zdaniem obrażał rozsądek, więc skoro dopuszczamy takich ludzi do debaty i pozwalamy im mówić i pozwalamy obrażać i pozwalamy im zaprzeczać faktom, to być może ta strategia się powiedzie, ale ja ciągle mam nadzieję, że rozsądek będzie zwyciężał i rozum też.

JW.: No ale o tym, że Czajka zatopiła ruch Trzaskowskiego to można dzisiaj było przeczytać w "Gazecie Wyborczej". To nie jest/ samo wyłączenie telewizji publicznej nie wystarczy. Trzeba będzie wyłączać dalej!

MP: Spokojnie! To się jeszcze zobaczy, natomiast wspomniałeś o tym, że Rafał Trzaskowski jest nieskuteczny w swoim działaniu i taka łatka może przylgnąć czy też przylgnęła do niego. Nie, no przyznam, że się nie do końca zgadzam. No bo tak - jednak trzeba pamiętać o tym, że jeśli chodzi o wybory prezydenckie w Warszawie - wygrał. I to wygrał w pierwszej turze. No, nawiasem mówiąc, jego rywal, Patryk Jaki, no powinien tutaj naprawdę dziękować opatrzności

JW.: Che, che.

-że nie ma tego pasztetu z „Czajką”, bo to/ no, jestem ciekaw, jak by wówczas wszystko się działo. Być może zresztą byłoby to oczywiście zrzucone na ekipę teoretycznie poprzednią, czyli panią prezydent Gronkiewicz-Waltz, tak? Nieudana konstrukcja „Czajki”, jak wiemy, nie jest prawdą. No właśnie, czyli wygrał wybory warszawskie, wygrał/ nie wygrał, no ale był bliski remisu, naprawdę bliski remisu i to trzeba pamiętać, że to w zasadzie z niczego. Poparcie dla kandydatów Platformy Obywatelskiej, Koalicji Obywatelskiej w wyborach prezydenckich przez pewien czas było jednocyfrowe, natomiast no on doprowadził, oczywiście z potężną/ jednak dosyć dużym wsparciem swojego sztabu i potężną mobilizacją wyborców, prawie że do remisu. To nie wydaje mi się, żeby tutaj pojawiła się na stałe ta łatka nieudacznika. Co więcej, no, mieszkańcy Warszawy, ludzie, którzy mają/ 
JW.: Nie nieudacznika - pechowca.

MP: Czy ja wiem?

JW.: To brzmi o wiele lepiej.

MP: Zauważcie, jak funkcjonuje Warszawa pod rządami Rafała Trzaskowskiego? Funkcjonuje całkiem nieźle. Oprócz tej nieszczęsnej historii z „Czajką”, no to ma po prostu typowe problemy dla dużego miasta, ale jednocześnie zmienia się i to się zmieniała zarówno pod rządami Hanny Gronkiewicz-Waltz, jak i teraz Rafała Trzaskowskiego po prostu na plus. Że naprawdę ludzie to widzą i między innymi był to też jakiś sprzeciw wobec kandydatury P. Jakiego. Ale między innymi dlatego wybrali Trzaskowskiego. Ja bym tutaj nie przesadzał z tym nieudacznictwem obecnego prezydenta Warszawy.

JW.: Im chodzi tylko o to, że jak robisz nowy ruch społeczny, czyli jednak próbujesz jakąś nową jakość, no a masz taką co roku tę samą wpadkę, to jest trudno to połączyć po prostu. Nie chodzi o nieudacznika. Pechowiec, no, fajny chłopak, ale pechowiec, nie? Nie myślicie, że to jest ta łatka, która przylgnie?

MP: Nie, niekoniecznie. Poczekajmy, zobaczmy. I tutaj, tak jak wspomniałem/ i wydaje mi się, że paliwa może dostarczyć Trzaskowskiemu Zjednoczona, Zjednoczona Prawica. Rzeczywiście jest ten pech. Rzeczywiście ten start jest być może za późny, a nawet na pewno zbyt późno, no i taki bym powiedział dosyć niemrawy. Natomiast nie przesądzając, w polityce nie da się niczego przesądzić.

JW.: Musimy kończyć.

\section{Ćwiczenie 1. Dobierz najtrafniejsze objaśnienia do podanych słów i wyrażeń:}
A) ruch społeczny
B) partia polityczna
C) radny dzielnicy
D) prezydent
E) rywal polityczny
F) kandydat
G) zaangażowanie polityczne
H) poparcie polityczne

1) poświęcenie czasu, sił i energii dla realizacji celów politycznych

2) uznanie, aprobata dla określonych polityków, partii; pomoc w ich działaniu

3) forma zbiorowego, spontanicznego działania obywateli zmierzająca do określonego celu, często do wywołania zmiany społecznej

4) polityk współzawodniczący z kimś, ubiegający się jednocześnie z kimś o władzę

5) organizacja społeczna o określonym programie politycznym, mająca na celu jego realizację poprzez zdobycie władzy

6) osoba stojąca na czele państwa lub miasta

7) członek rady dzielnicy, czyli organu władzy samorządowej

8) osoba ubiegająca się o jakieś stanowisko lub członkostwo w jakiejś grupie

Odpowiedzi do ćwiczenia 1:

\begin{tabular}{|c|c|c|c|c|c|c|c|}
\hline A & B & C & D & E & F & G & H \\
\hline 3 & 5 & 7 & 6 & 4 & 8 & 1 & 2 \\
\hline
\end{tabular}


Ćwiczenie 2. Połącz czasownik z pasującym dopełnieniem.
A) wygrać
1) awarię
B) pogrzebać
2) inicjatywę
C) popierać
3) projekt
D) zmobilizować
4) obietnicę
E) złożyć
5) błąd
F) usunąć
6) zwolenników
G) mieć
7) wybory
H) popełnić
8) pecha

Odpowiedzi do ćwiczenia 2:

\begin{tabular}{|c|c|c|c|c|c|c|c|}
\hline $\mathrm{A}$ & $\mathrm{B}$ & $\mathrm{C}$ & $\mathrm{D}$ & $\mathrm{E}$ & $\mathrm{F}$ & $\mathrm{G}$ & $\mathrm{H}$ \\
\hline 7 & 2 & 3 & 6 & 4 & 1 & 8 & 5 \\
\hline
\end{tabular}

Ćwiczenie 3. Połącz pasujące człony wyrażenia.
A) zrzucić coś
1) w pierwszej turze
B) wygrać wybory
2) obietnice wyborcze
C) wprowadzić
3) przepisy w życie
D) wyrazić poparcie
4) na poprzednią ekipę
E) realizować
5) dla kandydatów partii
F) kierować się
6) interesem publicznym

Odpowiedzi do ćwiczenia 3:

\begin{tabular}{|l|l|l|l|l|l|}
\hline A & B & C & D & E & F \\
\hline 4 & 1 & 3 & 5 & 2 & 6 \\
\hline
\end{tabular}

Ćwiczenie 4. Dopasuj wyraz bliskoznaczny do podanego.
A) pechowiec
1) obraz
B) awaria
2) katastrofa
C) zaangażowanie
3) nieudacznik
D) wizerunek
4) nietrwały
E) niemrawy
5) emocje
F) efemeryczny
6) działacz
G) aktywista
7) powolny

Odpowiedzi do ćwiczenia 4

\begin{tabular}{|c|c|c|c|c|c|c|}
\hline A & B & C & D & E & F & G \\
\hline 3 & 2 & 5 & 1 & 7 & 4 & 6 \\
\hline
\end{tabular}




\section{Ćwiczenie 5. Uzupełnij zdania odpowiednim rzeczownikiem we właściwej formie.}
A) Czy
Czajki obciąża prezydenta miasta stołecznego?
B) Czy prezydent popełnił błąd, nie biorąc się za organizację ruchu społecznego zaraz po .......?
C) Nie ma mowy o żadnych nowych inicjatywach, zanim usunięta. Czajki nie zostanie
D) Prezydent miasta zajmie się sprawą, która dotyczy jego sprzed kilku lat.
E) Czy przylgnie do prezydenta że jest nieskuteczny?
F) Prezydent nie zdoła uciec od nieudacznika.

1. wyborcy 2. rozszczelnienie 3. wizerunek 4. awaria 5.wybory 6. łatka

Odpowiedzi do ćwiczenia 5

\begin{tabular}{|c|c|c|c|c|c|}
\hline $\mathrm{A}$ & $\mathrm{B}$ & $\mathrm{C}$ & $\mathrm{D}$ & $\mathrm{E}$ & $\mathrm{F}$ \\
\hline 2. rozszczelnienie & 5. wyborach & 4. awaria & 1. wyborców & 6. łatka & 3. wizerunku \\
\hline
\end{tabular}

Ćwiczenie 6. Uzupełnij zdania odpowiednim czasownikiem we właściwej formie, użyj czasu przeszlego.
A. Czy politycy wyborców?
B. Paliwa dla opozycji w Polsce obóz rządzący.
C. Do gospodarza miasta łatka nieudacznika.
D. Warszawa dobrze pod rządami poprzedniej ekipy.
E. Awaria Czajki ................... inicjatywę powołania przez prezydenta ruchu społecznego.

1. dostarczać 2. funkcjonować 3. pogrzebać 4. przylgnąć 5. zmobilizować

Odpowiedzi do ćwiczenia 6

\begin{tabular}{|c|c|c|c|c|}
\hline A & B & C & D & E \\
\hline 5. zmobilizowali & 1. dostarczył & 4. przylgnęła & 2. funkcjonowała & 3. pogrzebała \\
\hline
\end{tabular}

\section{Ćwiczenie 7. Wyjaśnij znaczenie następujących wyrażeń}
A) zdrowy rozsądek
B) mieć pasztet z czymś
C) (coś) diabli wzięli

Odpowiedzi do ćwiczenia 7
A) zdolność racjonalnego myślenia i obiektywnej oceny sytuacji
B) być w kłopotliwej sytuacji z powodu czegoś
C) coś zostało bezpowrotnie utracone, przepadło 


\section{Ćwiczenie 8. Odpowiedz na pytania na podstawie tekstu.}

1. Dlaczego awaria oczyszczalni ścieków „Czajka” jest różnie nazywana?

2. Dlaczego R. Trzaskowski popełnił błąd, nie organizując swojego ruchu zaraz po wyborach?

3. W jakich rolach społecznych występuje R. Trzaskowski? Czy te role dadzą się pogodzić?

4. Jak można rozumieć określenie ,paliwo wyborcze”?

5. Co to jest wizerunek polityka?

Przykładowe odpowiedzi do ćwiczenia 8.

1. Zwolennicy prezydenta używają określenia „rozszczelnienie”, a przeciwnicy „katastrofa”. Słowa mogą być neutralne bądź zawierać ocenę pozytywną lub negatywną, mogą pomniejszać lub wyolbrzymiać opisywaną sytuację. Zależy to nie tyle od samej sytuacji, co od celu politycznego osoby nazywającej.

2. Po wyborach elektorat był zmobilizowany i nastawiony entuzjastycznie do projektu nowego ruchu społecznego. Według komentatorów z upływem czasu emocje nieco opadły, a odgrywają one niebagatelną rolę w procesach politycznych.

3. R. Trzaskowski jest prezydentem Warszawy i jako popularny polityk opozycji zamierza powołać ruch społeczny Nowa Solidarność współpracujący z PO. Pełni więc jednocześnie rolę publiczną i polityczną. Opinie na temat pogodzenia tych ról zależą od bieżącego interesu politycznego: zwolennicy prezydenta sprzyjają jego inicjatywom, przeciwnicy zarzucają mu, że nie wywiązuje się ze swoich obowiązków jako gospodarz miasta.

4. „Paliwo wyborcze”, to metaforyczne określenie wszystkich czynników sytuacyjnych, które sprzyjają danej opcji politycznej w zyskiwaniu poparcia jak najszerszego kręgu wyborców. Mogą być wyrazem uznania dla danej partii bądź niechęci do jej przeciwników.

5. Wizerunek polityka to sposób jego przedstawiania wyborcom. Jest on kreowany intencjonalnie często przez specjalistów. Wizerunek nie musi być zgodny z opinią o polityku. Ta bywa stronnicza na skutek różnej oceny jego działań, a nawet sympatii bądź antypatii bez podstaw racjonalnych.

Ćwiczenie 9. Wyszukaj w tekście lub zaproponuj samodzielnie, jakich argumentów mogą użyć ci, którzy kreują pozytywny wizerunek prezydenta, a jakich ci, którzy są jego przeciwnikami.

Przykładowa odpowiedź do ćwiczenia 9.

Zwolennicy: zdobył poparcie wyborców wystarczające do wygrania wyborów na gospodarza stolicy, zmienia miasto, dobrze nim zarządza.

Przeciwnicy: dopuścił do drugiej z rzędu katastrofy oczyszczalni ścieków, nie potrafi skutecznie zarządzać, przegrał wybory prezydenckie.

\section{Ćwiczenie 10. Wyszukaj samodzielnie informacje na temat telegeniczności polity- ków. Na czym polega ta cecha?}

Przykładowa odpowiedź do ćwiczenia 10.

Telegeniczny to tyle, co prezentujący się korzystnie w mediach. Media kreują polityków jak aktorów. Ich ubiór, charakteryzacja, sposób zachowania, gesty mają budzić sympatię widzów. Miła powierzchowność jest równie ważnym elementem wizerunku, co wiedza i umiejętności profesjonalne. Czasem telegeniczność może polegać na prowokacji i kontrowersji. 


\section{PODSUMOWANIE}

Za włączeniem medialnych tekstów publicystycznych do puli materiałów dydaktycznych przemawia kilka argumentów. Przede wszystkim teksty tego rodzaju jako jedyne realizują kilka wymaganych na poziomie $\mathrm{C} 2$ zakresów tematycznych, gdyż relacjonują aktualne wydarzenia polityczne i poruszają ważne sprawy publiczne. Zwykle jednostkowa bieżąca sprawa uruchamia w publicystyce pogłębione analizy, które w zależności od kompetencji dziennikarza mogą edukować odbiorcę medialnego, wyjaśniać mu prawidłowości procesów politycznych. Tak więc to, co aktualne, zyskuje sens dopiero na tle ogólnych prawidłowości komunikowania politycznego. Ujawnianie mechanizmów i strategii dyskursu publicznego zwiększa świadomość odbiorcy i podnosi jego kompetencje interpretacyjne. Dodatkowo kontakt z tekstem dialogowym, w którym ujawniają się różnice stanowisk sprzyja rozwijaniu krytycyzmu. Można przyjąć, że celem tego rodzaju kształcenia specjalistycznego jest skłonienie odbiorcy do porzucenia uproszczonego, potocznego odbioru przekazów politycznych na rzecz przyjęcia perspektywy zbliżonej do kompetencji eksperta.

\section{BIBLIOGRAFIA}

Adamik-Szysiak M. (red.), 2015, Mediatyzacja komunikowania politycznego. W kręgu badań politologicznych i medioznawczych, Lublin.

Adamik-Szysiak M. (red.), 2016, Polityka w zmediatyzowanym świecie. Perspektywa politologiczna i medioznawcza, Lublin.

Balkowska G., 2013, Teksty publicystyczne w programie kursu języka polskiego dla grupy ekonomicznej, „Acta Universitatis Lodziensis. Kształcenie Polonistyczne Cudzoziemców”, t. 20, s. 281-292.

Bucko D., 2017, Jak efektywnie wykorzystać teksty internetowe podczas lekcji języka polskiego jako obcego, ,Języki Obce w Szkole”, nr 4, s. 84-89.

Data K., 2000, Teksty mówione w nauczaniu na poziomie zaawansowanym, w: J. Mazur (red.), Polonistyka w świecie. Nauczanie języka i kultury polskiej studentów zaawansowanych, Lublin, s. $157-161$.

Data K., 2001, Struktura tekstu w nauczaniu języka polskiego, w: R. Cudak, J. Tambor (red.), Inne optyki. Nowe programy, nowe metody, nowe technologie w nauczaniu kultury polskiej i języka polskiego jako obcego, Katowice, s. 119-124.

Dobek-Ostrowska B., 2006, Komunikowanie polityczne i publiczne, Warszawa.

Fras J., 2010, Tabloidyzacja a mediatyzacja i logika mediów - wzajemne relacje pojęć, w: Wspótczesne media. Wolne media? t.2, I. Hoffman, D. Kępa-Figura (red.), Lublin, s. 59-72.

Kron F.W., Sofos A., 2008, Dydaktyka mediów, Gdańsk.

Kubiak B., 2009, 2012, Na łamach prasy. Podręcznik do nauki języka polskiego. Ćwiczenia rozwijajace sprawność czytania (C2), cz. I, cz. 2, Kraków.

Molęda-Zdziech M., 2013, Czas celebrytów. Mediatyzacja życia publicznego, Warszawa.

Mrozowski M., 2001, Media masowe. Władza, rozrywka i biznes, Warszawa. 
Ogonowska A., 2013, Współczesna edukacja medialna: teoria i rzeczywistość, Kraków.

Oniszczuk Z., 2011, Mediatyzacja polityki i polityzacja mediów. Dwa wymiary wzajemnych relacji, „Studia Medioznawcze” nr 47, s. 11-23.

Janowska I., Lipińska E., Rabiej A., Seretny A., Turek P. (red.), 2016, Programy nauczania języka polskiego jako obcego. Poziomy A1-C2, Kraków.

Przybylska R., 2008, O potrzebie tworzenia korpusów tekstów do nauczania języka polskiego jako obcego, w: W. Miodunka, A. Seretny (red.), W poszukiwaniu nowych rozwiazań. Dydaktyka języka polskiego jako obcego u progu XXI wieku, Kraków, s. 31-34.

Rabiej A., 2010, Teksty użytkowe w nauczaniu języka polskiego jako obcego, „Acta Universitatis Lodziensis. Kształcenie Polonistyczne Cudzoziemców”, t. 17, s. 293-302.

Skarżyńska K. (red.), 2002, Podstawy psychologii politycznej, Poznań.

Żydek-Bednarczuk U., 2014, Tekst medialny w edukacji glottodydaktycznej, „Acta Universitatis Lodziensis. Kształcenie Polonistyczne Cudzoziemców”, t. 21, s. 335-344.

Edyta Pałuszyńska

\section{JOURNALISTIC TEXTS IN DEVELOPING COMMUNICATIVE COMPETENCE AT THE C2 LEVEL. FEATURES OF PUBLIC AND POLITICAL DISCOURSE IN MEDIA}

Keywords: teaching Polish as a foreign language, communicative competence, discourse, political communication, media

Summary. The main purpose of this article is to discuss the features of a selected type of didactic material, which is a spoken dialogic journalistic text from the media (in short: SDJTM). I assume that the proposed text type fulfils such curricular requirements at the $\mathrm{C} 2$ level as authenticity, topicality, interactivity, mediality, and discursivity, and in a special way serves the development of comprehension and speaking skills. The potential of the selected type of text is planned as the topic of a series of articles. The first one is devoted to the features of public and political discourse in the media. This article is divided into three parts: the first discusses how to prepare the didactic material, the benefits and problems associated with its use; the second introduces selected features of public and political discourse that allow more accurate interpretation of the meaning of interaction; the third contains a transcript of a 10-minute long journalistic dialogic text downloaded as a podcast from TOK FM Radio with exercises. 